(Advertisement)

\title{
POSITION AVAILABLE
}

The Pathology Department, International Potato Center, Apartado 5969, Lima 100-Peru, announces a position for a Plant Virologist to assume responsibility for testing for viruses in the Center's Seed Potato Program, and to train national program scientists in techniques of virus detection and elimination. The principal part of the work will be done in Peru but travel to other countries to conduct training will be necessary. As part of a team of virologists with well equipped facilities and adequate technician support, there will be opportunity for research on the determination of new virus strains or novel viruses present in the Andean potato growing areas.

Applicants must have a Ph.D. in virology and at least five years of professional experience in this field.

Knowledge of potato viruses is not essential, but desirable. Please contact E.R. French, head of the Pathology Department, for application forms (air mail).

\section{ERRATA}

Through a mysterious series of events, the figures that appeared in two articles by W. M. Roca, et al, in the December 1978 and January 1979 issues of the Journal were transposed. Figures 1 and 2 that were printed with the December article (Bol 55 Number 12) "A tissue culture method for the rapid propagation of potatoes," should have appeared in the January article (Volume 56 Number 1) "Tissue culture for the international transfer of potato genetic resources." Conversely, the two figures in the January article should have appeared in the December article. 